\title{
Prof. Dr. Riskó Tibor ortopéd sebész (1923-2017)
}

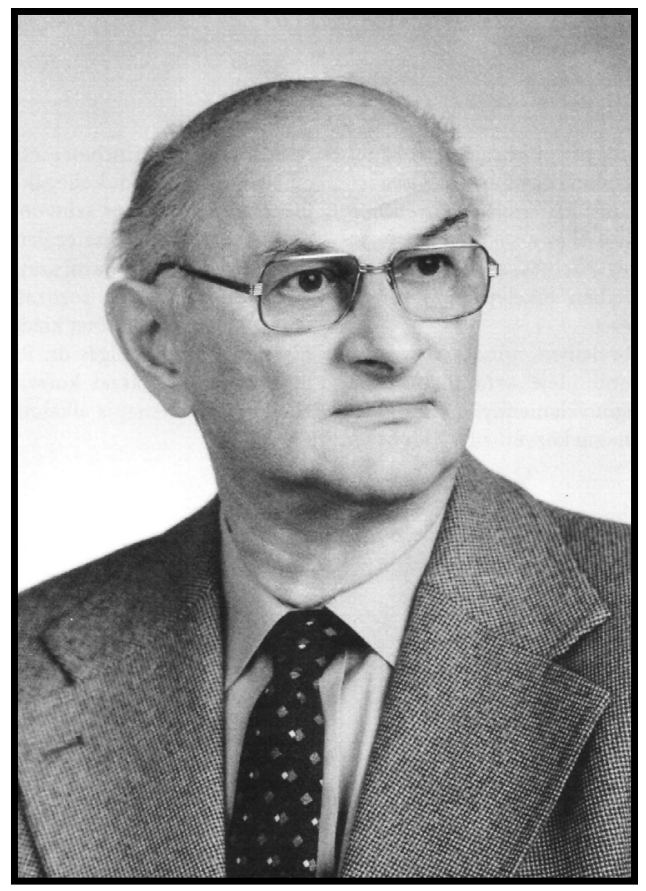

Riskó Tibor Debrecenben született 1923. július 4-én. Ugyanitt kezdte meg orvosegyetemi tanulmányait 1941ben, majd 1944-ben Budapesten folytatta. A háború miatt a Magyar Egyetemek Orvostudományi Karával, Halle-Saale-ban tanult 1944-1945-ben. A szocialista rendszer az így szerzett orvosi doktori végzettségét nem ismerte el, ezért 1946-1948 között újra beiratkozott Debrecenben. 1949 és 1952 között a kakasszéki Csontízületi tbc és Mellkassebészeti Osztály vezető foorvosa volt. 1952-től 1965-ig a budapesti Fodor József Tbc Gyógyintézet igazgató foorvosa. 1965-tôl 1976-ig az Országos Korányi Tbc és Pulmonológiai Intézet Ortopéd Sebészeti Osztályának vezetője volt. 1972-1981: az Országos Ortopédiai Intézet igazgatóhelyettese; 19741986: az Egészségügyi Főiskolai Kar Gyógytornászképző Szakának vezetője; 1976-1984: az Országos Reumatológiai és Fizioterápiás Intézet (ORFI) Ortopédiai Osztályának vezetője; 1977-1982: az Orvostovábbképző Egyetem (OTE) Reumatológiai Tanszékén egyetemi tanár. 1982 és 1988 között ortopédiai tanszékvezető egyetemi tanár volt. 1988-ban vonult nyugdíjba az OTE-HIETE (Haynal Imre Egészségtudományi Egye- tem) tiszteletbeli professzoraként. Budapesten hunyt el 2017. február 5-én. 2017. március 16-án megemlékezést tartottak Prof. emeritus Dr. Riskó Tibor tiszteletére az MTA klubtermében.

Jelen cikk szerzője 2014-ben egy hosszú interjút készített Riskó Tiborral, abból közlünk itt egy összefoglalót:

V. J.: Úgy olvastam, hogy a Riskó családnak volt kapcsolata a XIX. század zseniális költőjével, Petőfi Sándorral.

R. T.: Nagyon messzire tudtam vezetni a családfánkat, már az édesapám is foglalkozott ezzel a témával. A $M a-$ gyar Családtörténeti Szemlében az egész család története le van írva. Nagy Iván: Magyarország családjai című hatkötetes könyvében írja a Riskó családról: Kövesligeti Szatmár megyei nemesi család, a század elején birtokos volt. Mihály 1816-ban a Nagyváradi káptalan uradalom számvevője, Ignác 1849-ben Szatmár megye aljegyzője. Ez az Ignác történelmi szempontból nagyon jelentős, mert náluk lakott (az aljegyzőnél) Petőfi és ő ismertette össze Szendrey Júliával.

V. J.: A középiskoládat hol végezted?

R. T.: A Munkácsi m. kir. Árpád Fejedelem Gimnáziumban. 1941-ben érettségiztem és neked köszönhetően megkaptam a gimnáziumunk évkönyvét. Büszke vagyok, mert én mondtam a ballagási beszédet. Turchányi György fizikatanárom volt az osztályfőnököm, aki később a Semmelweis Egyetem Biofizika Tanszékén lett egyetemi tanár. Az ő lakásán tartottuk az 50 éves találkozónkat.

V. J.: Mikor nôsültél meg?

R. T.: A feleségem német-angol-francia bölcsészszakot végzett. Nagyon fiatalon házasodtunk össze. A II. világháború vége felé, 1944-ben úgy döntöttek, hogy a végzős orvostanhallgatókat kiviszik Halléba. Én Halléba vittem magammal a feleségemet. Megnősültem, mielőtt kimentem, mert a szüleim ragaszkodtak hozzá, hogy csak akkor vihetem a mennyasszonyomat, ha feleségül veszem. Ö jött velem boldogan. A feleségem aránylag korán meghalt rákban (1996-ban). Négy gyermekünk született: Zoltán (1945), Ágnes (1946), Géza (1949), Judit 1954; 11 unokám és hét dédunokám van.

V. J.: Mondjál valamit a hallei oktatásról!

R. T.: Nagyon nagy professzorok voltak az előadók: Hüttl Tivadar (rektor), Orsós Ferenc (dékán), Frank 


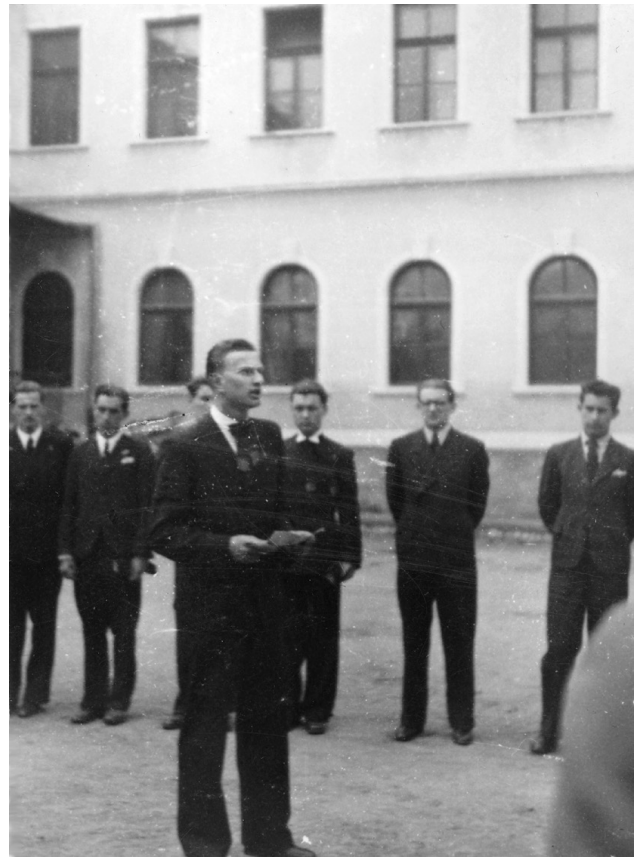

1. ábra Riskó Tibor mondja a ballagási beszédet (Munkács) 1941. június 26-án

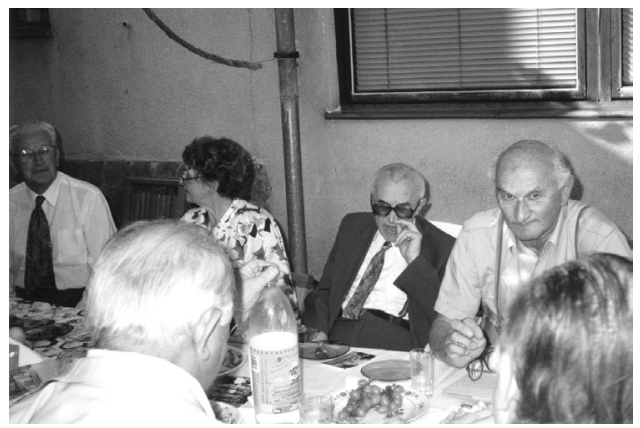

2. ábra

Ötvenéves osztálytársi találkozó Prof. Dr. Turchányi György lakásán Budapesten

Kálmán (gyermekgyógyász). Orsós volt annak a nemzetközi bizottságnak az elnöke, aki megállapította, hogy Katyñban nem németek gyilkolták meg a lengyel tiszteket, hanem a szovjetek. Ilyen professzorok tartották az előadásokat és szigorlatokat. Nem volt könnyű szigorlatozni. Így például törvényszéki orvostanból úgy szigorlatoztunk Orsósnál, hogy valamilyen jobb ruhánkat, ami volt, felvettük, mert akkor már az amerikaiak lőtték Hallét és árokba kúszva mentünk ki a professzorhoz. Mi medikusok egy laktanyában laktunk, a professzoroknak külön villájuk volt a városon kívül és így odakúsztunk a villához szigorlatozni.

V. J.: Mi történt a háború után?

R. T.: A szüleimmel együtt visszatértünk Debrecenbe, ám ott nem ismerték el a hallei diplomámat, így a második szigorlattól kezdve minden vizsgát újra le kellett tennem. Nem tudtam dolgozni, nem volt fizetésem. Az édesapám akkor már meghalt, az édesanyámnak ötven forint volt a nyugdíja. Kecskéket tartottam, a tejet még el is adtam. Miután megszereztem az utolsó vizsgát is, kaptam még egy diplomát. Itt van a falon az orvosi végzettségemet igazoló mindkét diplomám.

V. J.: 1956-ról?

R. T.: A Fodor József Gyógyintézet igazgatója voltam. Itt éltük át az 1956-os forradalmat is. Sok nehézséggel, de biztosítani tudtuk a 400 beteg és a hozzánk került sebesültek ellátását. Egyikük, Márity László, Budakeszi 1956-os mártírja, sajnos erőfeszítésünk ellenére az intézetben halt meg. Róla Budakeszin utcát is elneveztek. Az intézetünkkel kapcsolatos 1956-os eseményekről Erdőss Pál rendezésében, neves színészek közremúködésével film is készült, amelyet a forradalom 50 . évfordulóján mutattak be, „Budakeszi srácok” címmel. Ez Erdőss Pál utolsó rendezése volt, nem sokkal később elhunyt. A forgatókönyv Kovács István, a kitűnő író, költő, történész, diplomata könyve, „A gyermekkor tündöklete” alapján készült. Személyes élményei alapján írta, hiszen gyermekkorát, a forradalom heteit a Fodor-szanatóriumban élte meg. Édesanyja ott dolgozott.

V. J.: Úgy hirlik, te ,fedezted fel” dr. Medve Lászlót, a késöbbi minisztert.

R. T.: Országos intézet igazgatóhelyetteseként gyakran jártam kiszállásokra, dr. Mosolygó Dénessel együtt. Hazafelé jövet a fóosztályvezető megkérdezte, kikkel találkoztam. Azt feleltem egyik ilyen alkalommal, hogy nagyon jó benyomást tett rám egy értelmes, fiatal doktor - Medve László a neve. Fél évvel később Dénes felhívta magához, minisztériumi előadó lett, majd saját tehetségének köszönhetően miniszter. Medve László ezt sosem felejtette el nekem. Nem sokkal a halála előtt találkoztunk az Akadémia elött, és azt mondta: „Tibor, ha te akkor nem jössz el Lengyeltótiba, legfeljebb ott föorvos lettem volna és nem miniszter."

V. J.: Egy betegedhez füzödö érdekes élményedet mondd el!

R. T.: Elmondok egy megható történetet. Itt van egy kristályváza, amiben van egy szalag, rá van írva „1961.08.20. Pécs. Gyorsasági bajnokság az Auto-motor Klub, Tisztelet-díj". Soha az életemben nem motoroztam, nem versenyeztem, és így Pécsett sem vettem részt semmilyen versenyen. E vázában mégis a birtokomban van egy tiszteletdíj. Ez a váza ennek az ott elért helyezésnek a vázája volt. Ezt egy fiatalember hozta el hozzám, akire én már nem is emlékeztem, tudniillik neki még kisgyerek korából csigolyatuberkulózisa volt, amit összevissza kezeltek, nem operálták meg és végül megbénult és hozzám bénultan került. Aztán megoperáltam és rendbe jött. A régi bénult állapota után megnyerte a pécsi versenyt. A kristályváza és a díj azért került hozzám, mert egyszer megjelent nálam ez a fiatal és azt mondta: „Doktor bácsi! Ezt maga nyerte.” Rettenetesen meghatódtam. Ilyenek vannak. Az ember sok minden ajándékot kapott életében, de ezt senkinek oda nem adom.

Vincze János dr. 